Metallurgy-Raw Materials

$-1=$

This document consists of $\mathcal{Y}$ /pages. No. 28 of 20 copies. Series. $A$.

TOPICAL REPORT WIN-3

ACID AND CARBONATE LEACHING OF NORTH JACKPILE ORE

By

J. Q. Jones, J. B. Larson, J. T. Lynch, E. S. Porter,

G. Trueman, and H. I. Viklund

Classificati in cance"'ed (or changed to UNCLASSIFIED

by authority of Memofrem D. R A ty $9-19-55$

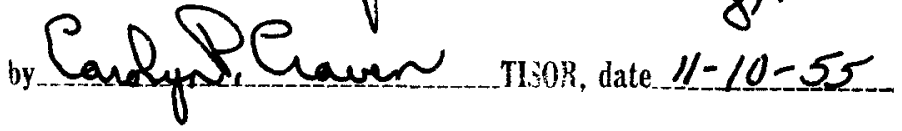

February 21, 1955

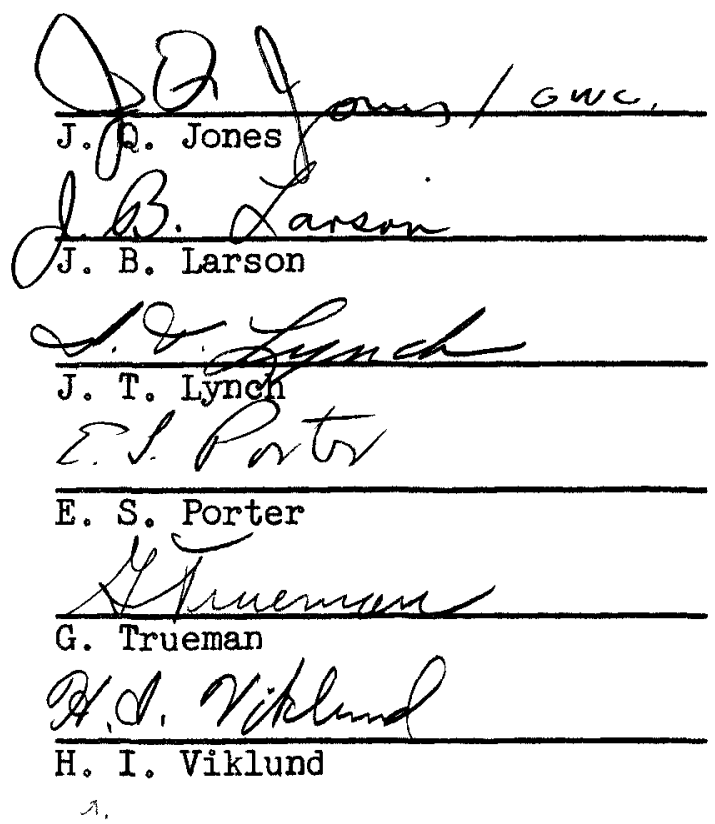

This document is PUBLICLY RELEASABLE ORO Review Team Authorizing Official Date $11-9-2010$

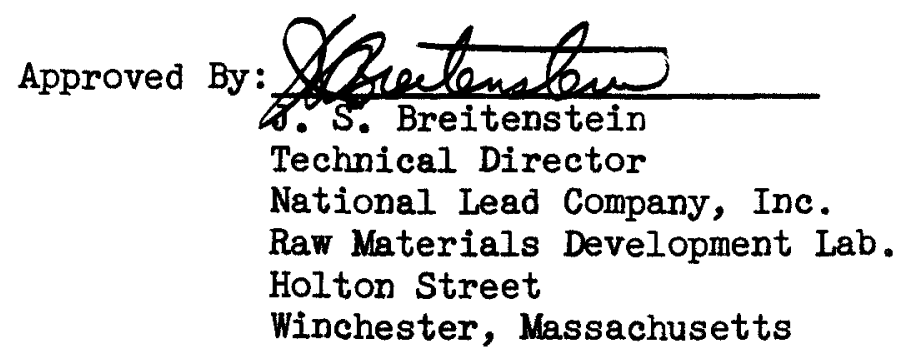

UNCLASSIFIED 


\section{DISCLAIMER}

This report was prepared as an account of work sponsored by an agency of the United States Government. Neither the United States Government nor any agency Thereof, nor any of their employees, makes any warranty, express or implied, or assumes any legal liability or responsibility for the accuracy, completeness, or usefulness of any information, apparatus, product, or process disclosed, or represents that its use would not infringe privately owned rights. Reference herein to any specific commercial product, process, or service by trade name, trademark, manufacturer, or otherwise does not necessarily constitute or imply its endorsement, recommendation, or favoring by the United States Government or any agency thereof. The views and opinions of authors expressed herein do not necessarily state or reflect those of the United States Government or any agency thereof. 


\section{DISCLAIMER}

Portions of this document may be illegible in electronic image products. Images are produced from the best available original document. 
WIN-3

Metallurgy-Raw Materials

-2 -

External Distribution

Allied Chemical and Dye Corp., General Chemical Division Argonne National Laboratory

Atomic Energy Commission, Washington

Battelle Memorial Institute

Carbide and Carbon Chemical Company (K-25)

Carbide and Carbon Chemical Company (ORNL)

Chicago Patent Group

Columbia University (Hassialis)

Division of Raw Materials, Washington, D. C.

Dow Chemical Company, Pittsburg

General Electric Company, Richland

Grand Junction Operations Office

Hanford Operations Office

International Minerals and Chemical Corporation

Iowa State College

Arthur D. Little, Ine.

Los Alamos Scientific Laboratory

Mallinckrodt Chemical Works

Massachusetts Institute of Technology (Prof. A. M. Gaudin)

National Lead Company of Ohio

New Brunswick Laboratory

New York Operations Office

Patent Branch, Washington

Rohm and Haas Company

Technical Information Service, Oak Ridge

Tennessee Valley Authority

Texas City Chemicals, Inc.

U. S. Bureau of Mines, Salt Lake City

U. S. Geological Survey

University of California Radiation Laboratory, Berkeley

University of Nevada, Mackay School of Mines

Virginia_Carolina Chemical Corporation

Copy No. (Series A)

$$
\begin{gathered}
1 \\
2-3 \\
4-5 \\
6 \\
7 \\
8-11 \\
12 \\
13-14 \\
15-26 \\
27 \\
28-31 \\
32-35 \\
36 \\
37 \\
38 \\
39 \\
40 \\
41 \\
42 \\
43 \\
44 \\
45 \\
46 \\
47 \\
48-57 \\
58 \\
59 \\
60 \\
61-62 \\
63 \\
64 \\
65 \\
\end{gathered}
$$

Internal Distribution

R. F. Hollis

66

Library

$67-70$

Series MC 
TOPICAL REPORT WIN-3

\title{
ACID AND CARBONATE LEACHING OF NORTH JACKPIIE ORE
}

\author{
By \\ J. Q. Jones, J. B. Larson, J. T. Lynch, E. S. Porter, \\ G. Trueman, and H. I. Viklund
}

\begin{abstract}
$\underline{A} \underline{B} \underline{S} \underline{T} \underline{R} \underline{A} \underline{C} \underline{T}$
Laboratory investigation of a composited drill core sample from the North Jackpile ore body near Grants, New Mexico, revealed that the ore is readily amenable to acid leaching and ion exchange. Good settling rates were obtained on neutral and acid leached pulps. An oxidant was beneficial to leaching.

Carbonate leaching was also effective either with a chemical oxidant or following a preliminary roast. Filtration of carbonate leached pulps was difficult.
\end{abstract}




\section{$\underline{\text { Page }}$}

ABSTRACT

I. INTRODUCTION 5

II. SUMMARY 6

III. SAMPLE PREPARATION AND MINERALOGICAL DESCRIPTION 7

$\begin{array}{ll}\text { A. Sample Preparation } & 7 \\ \text { B. Mineralogical Examination } & 7\end{array}$

IV. METALLURGICAL INVESTIGATIONS 8

A. Acid Leaching 8

1. Single Stage Acid Leaching 8

2. Two-Stage Acid Leaching 9

3. Ion Exchange Testing 9

4. Settling Tests 10

B. Carbonate Leaching 11

1. Test Procedures 11

2. Effect of Roasting and Oxidant 12

3. Effect of Leaching Time 13

4. Effect of Pressure and Temperature 13

C. Filtration Tests 14

APPENDIX 


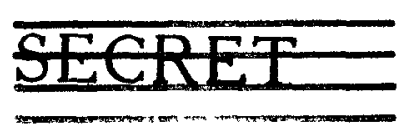

WIN-3

$-5-$

TOPICAL REPORT WIN-3

\section{ACID AND CARBONATE IEACHING OF NORTH JACKPILE ORE}

\section{By}

J. Q. Jones, J. B. Larson, J. T. Lynch, E. S. Porter

G. Trueman, and H. I. Viklund

\section{INTRODUCTION}

On June 25, 1954, a letter was received from Mr. J. B. Knaebel, Manager of the Anaconda Copper Mining Company's plant at Bluewater, New Mexico, in which he stated that a new ore body was being explored, and preliminary amenability test work had indicated that the ore from drill core samples was refractory to acid leaching.

A 100 pound sample of North Jackpile ore from exploratory drilling was received on July 14, 1954. This ore was identified by Anaconda as NJP-6-22 and assayed $0.207 \% \mathrm{U}_{3} 0_{8}$. Our code number for this ore is NL-77-3. At the request of the U. S. Atomic Energy Commission, a test program was initiated to investigate the extraction and recovery of uranium by acid and carbonate leaching. Pilot plant tests were run on North Jackpile ore in Grand Junction to determine its amenability to the RIP process. Since plans for a RIP plant at Bluewater, New Mexico were already well advanced to treat the other sandstone ores of the district, emphasis was placed on a laboratory study of the variables affecting acid leaching and ion exchange. Studies of a preliminary nature were made on the settling of neutral and acid leached pulps and on carbonate leaching and filtration of carbonate leached residues. 


\section{SUMMARY}

Laboratory investigations indicated that the North Jackpile ore, as represented by the sample submitted, is readily amenable to either acid leaching and RIP or to acid leaching followed by continuous ion exchange. Good extraction was also obtained by carbonate leaching but the ore would require either a preliminary roast or chemical oxidation and filtration would be difficult.

Uinety-six per cent of the uranium was extracted by leaching unground samples $(4.7 \%+28$ mesh -- $17.8 \%-200$ mesh) at $50 \%$ solids for four hours at ambient temperature with 60 to 75 pounds of sulfuric acid and five pounds of $85 \% \mathrm{MnC}_{2}$ per ton of feed.

Maximum extraction of uranium by acid leaching is favored by a redox potential during leaching of 500 to 600 millivolts. Without an oxidant, 3 to 5\% lower extractions were obtained.

Groinding to 28 mesh with about $10 \%$ on 35 mesh appears to be optimum for acid leaching. Finer grinding increased the consumption of acid and $\mathrm{MnO}_{2}$ and did not improve the extraction of uranium. A $10 \%+35$ mesh grind in the laboratory rod mill yielded about $25 \%$ of -200 mesh slimes。

Preliminary two stage acid leaching tests indicated that little could be gained by using this method rather than single stage leaching.

Thickening tests, before and after acid leaching, indicate a thickener area requirement of approximately 2.5 square feet per ton per 24 hours, using 0.1 pound of locust bean gum or other common flocculents and less than 10 square feet per ton without an additive. Terminal density was $55 \%$ for unleached pulp and $45 \%$ solids for the leached residues.

Ion exchange tests on acid leach solutions gave $99.9 \%$ recovery of uranium and a final product assaying $86.8 \% \mathrm{U}_{3} \mathrm{O}_{8}$. Consumption of reagents for elution and precipitation was about 0.84 pound of $100 \%$ $\mathrm{HCl}, 0.75$ pound of $\mathrm{NH}_{3}$, and 0.43 pound of $\mathrm{H}_{2} \mathrm{SO}_{4}$ per pound of $\mathrm{U}_{3} \mathrm{O}_{8}$ in the laboratory column tests.

Ninety-five per cent of the uranium was extracted from raw ore by leaching for 18 hours at $95^{\circ} \mathrm{C}$ with a solution containing 80 to 90 grams of $\mathrm{Na}_{2} \mathrm{CO}_{3}$ and 30 grams $\mathrm{NaHCO}_{3}$ per liter plus 10 pounds of $\mathrm{KMnO}_{4}$ per ton of feed. The same extraction was obtained without an oxidant by roasting for two hours at $450^{\circ} \mathrm{C}$ before leaching.

Leaching raw ore at elevated pressures and temperatures increased the rate but did not improve the extraction of uranium.

Filter rates for carbonate leached raw ore residues are of the order of 500 pounds per square foot per 24 hours. The addition of 0.3 pound of Dow X-2610 increased the filter rate by about $10 \%$ but produced a cake of $5 \%$ higher moisture content.

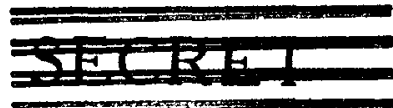




\section{SAMPLE PREPARATION AND MINERALOGICAL DESCRIPTION}

\section{A. Sample Preparation}

The ore received ranged in size from 1.25" to fines. The coarse material was composed of loosely cemented aggregates which disintegrated on handling and preliminary crushing was not required. The sample was split-weighed into 500 gram charges for test work and a random charge was submitted for chemical and spectrographic analyses. The results of these analyses are presented in Table $I$.

Table I

Head Analyses of North Jackpile Ore

Chemical Analyses

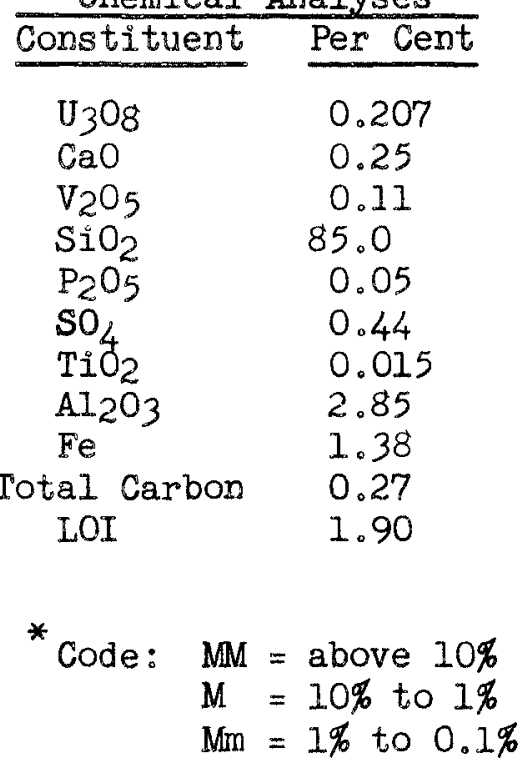

\begin{tabular}{llll}
\multicolumn{4}{c}{ Spectrographic } \\
\hline $\mathrm{Al}$ & $\mathrm{M}$ & $\mathrm{Mn}$ & $\mathrm{m}$ \\
$\mathrm{B}$ & $\mathrm{t}$ & $\mathrm{Mo}$ & $\mathrm{t}$ \\
$\mathrm{Ba}$ & $\mathrm{m}$ & $\mathrm{Na}$ & $\mathrm{Mm}$ \\
$\mathrm{Be}$ & $\mathrm{t}$ & $\mathrm{Ni}$ & $\mathrm{mt}$ \\
$\mathrm{Bi}$ & $\mathrm{mt}$ & $\mathrm{P}$ & $\mathrm{Mm}$ \\
$\mathrm{Ca}$ & $\mathrm{Mm}$ & $\mathrm{Pb}$ & $\mathrm{m}$ \\
$\mathrm{Cr}$ & $\mathrm{mt}$ & $\mathrm{Si}$ & $\mathrm{MM}$ \\
$\mathrm{Cu}$ & $\mathrm{mt}$ & $\mathrm{Sr}$ & $\mathrm{m}$ \\
$\mathrm{Fe}$ & $\mathrm{M}$ & $\mathrm{Ti}$ & $\mathrm{Mm}$ \\
$\mathrm{Ga}$ & $\mathrm{mt}$ & $\mathrm{V}$ & $\mathrm{Mm}$ \\
$\mathrm{Li}$ & $\mathrm{mt}$ & $\mathrm{Zr}$ & $\mathrm{m}$ \\
$\mathrm{Mg}$ & $\mathrm{Mm}$ & &
\end{tabular}

$$
\begin{aligned}
& m=0.1 \% \text { to } 0.01 \% \\
& m t=0.01 \% \text { to } 0.001 \% \\
& t=0.001 \%
\end{aligned}
$$

B. Mineralogical Examination I

The sample is a light brown to gray sandstone composed of fine sands cemented by clay, gypsum, minor carbonate, iron oxides, and the secondary uranium minerals. A massive, olive brown, slightly calcareous mudst,one, is also present. The uranium minerals are uranophane, autunite, carnotite and/or tyuyamunite and minor uraniferous hydrocarbon. The need of an oxidant during leaching suggests that approximately $5 \%$ of the uranium is in a reduced form, probably pitchblende. 


\section{METALIURGICAL INVESTIGATIONS}

The extraction and recovery of uranium by acid and carbonate leaching was investigated by two different groups at the laboratory. Messrs. Jones, Porter, Trueman and Lynch did the work on acid leaching. The carbonate leaching studies were performed by Messrs. Viklund and Larson. The first studies were on acid leaching. This consumed a large amount of the sample received and insufficient sample was available to make the carbonate leaching study as detailed as would be desired.

\section{A. Acid Leaching}

\section{Single Stage Acid Leaching}

The results of a series of single stage leaching tests on 250 gram charges of unground ore agitated at $50 \%$ solids in glass bottles on rolls are presented in Table II.

\section{Table II}

\section{Single Stage Acid Leaching Data}

No Grind $(10.4 \%+35$ mesh, $17.8 \%-200$ mesh $)$

Leaching Conditions: Ambient Temperature, $16 \mathrm{Hrs}$

\begin{tabular}{|c|c|c|c|c|c|}
\hline $\begin{array}{l}\mathrm{H}_{2} \mathrm{SO}_{4} \\
\mathrm{Lb} / \mathrm{T}\end{array}$ & $\begin{array}{l}\mathrm{MnO}_{2} \\
\mathrm{Lb} / \mathrm{T}\end{array}$ & $\begin{array}{l}\text { Per Cent } \\
\text { Extraction }\end{array}$ & $\begin{array}{c}\text { Residue } \\
\mathscr{\%}_{3} \mathrm{U}_{3} \mathrm{~g}\end{array}$ & $\mathrm{pH}$ & $\operatorname{Emf}$ \\
\hline 60 & 0 & 92.5 & .016 & 0.80 & -.455 \\
\hline 75 & 0 & 92.9 & .015 & 0.68 & -.420 \\
\hline 60 & 5 & 96.7 & .007 & 0.79 & -.545 \\
\hline 75 & 5 & 97.1 & .006 & 0.72 & -.521 \\
\hline 60 & 7.5 & 96.7 & .007 & 0.80 & -.680 \\
\hline
\end{tabular}

*Based on residue and feed assays.

The above table shows that extractions of 96 to $97 \%$ were obtained by leaching charges $10.4 \%+35$ mesh $(17.8 \%-200$ mesh) for 16 hours with five pounds of $85 \% \mathrm{MnO}_{2}$ and 60 to 75 pounds of $\mathrm{H}_{2} \mathrm{SO}_{4}$ per ton of ore. A high redox potential was required. Manganese dioxide is a satisfactory oxidant and it appears that enough should be added to give a terminal leaching solution potential of -500 to $-600 \mathrm{mv}$ as measured by platinum versus calomel electrodes.

Additional leaching data are presented in the Appendix, Table A-1, and screen analyses for an unground charge and charges ground for one and ten minutes respectively are shown in the Appendix, Table A-2.

Grinding finer than the natural grain size of the quartz is unnecessary for acid leaching. The optimum grind on the sample studied appears to be essentially all through 28 mesh with about $10 \%$ plus 35 mesh. This 
grind should produce from 18 to $25 \%$ of minus 200 mesh material and result in a moderately low dilution factor for efficient desanding of the leached pulp for RIP feed.

Extraction was not improved and the consumption of acid and $\mathrm{MnO}_{2}$ was increased by grinding to $100 \%$ minus 65 mesh.

Leaching of unground charges for four hours at ambient temperature with 60 to 75 pounds of $\mathrm{H}_{2} \mathrm{SO}_{4}$ and 5 to 7.5 pounds of $85 \% \mathrm{MnO}_{2}$ per ton resulted in uranium extractions of about 95\%. Leaching at a temperature of $60^{\circ} \mathrm{C}$ for four hours with 60 pounds of $\mathrm{H}_{2} \mathrm{SO}_{4}$ and 5 pounds of $85 \% \mathrm{MnO}_{2}$ extracted $97 \%$ of the uranium.

\section{Two-Stage Acid Leaching}

The single-stage acid leaching tests indicated that high extractions of uranium required the presence of considerable free acid ( $\mathrm{pH} 0.7$ to 0.8 ) at the end of leaching. Consequently, neutralization of the excess acid with limestone might be required before recovering uranium from the leach solutions by ion exchange. A two stage countercurrent acid leaching investigation was therefore made to determine the effect on the extraction of uranium and consumption of acid.

The flowsheet used in the two-stage leach is shown in the Appendix, Figure 1. Leaching times were two hours in the first on neutral leaching stage, and four hours in the second stage. All reagent additions were to the second stage. Eight cycles were completed and the results are presented in the Appendix, Table A-3. The acid was gradually reduced from 52 to 35 pounds per ton of ore, without materially affecting the uranium recovery. Five pounds of $85 \% \mathrm{MnO}_{2}$ per ton of ore were used in each cycle. Ore charges were in the as-prepared condition with about $10 \%+35$ mesh。

Under the test conditions, the uranium extraction (94\%) was about the same as that obtained with 60 pounds of acid per ton in a single-stage four hour leach. Higher extractions could be expected by increasing the leaching time in the second stage. The indicated saving of 20 to 25 pounds of $\mathrm{H}_{2} \mathrm{SO}_{4}$ per ton could not be fully realized in a CCD plant unless the barren solution could be used for washing. Little, if any, saving in leaching reagents could therefore be expected by two-stage leaching and CCD in preference to single-stage leaching and RIP.

\section{Ion Exchange Testing}

Pregnant solution for ion exchange was prepared by single-stage leaching ore ground for one minute, for 16 hours at $50 \%$ solids with 75 pounds of $\mathrm{H}_{2} \mathrm{SO}_{4}$ and 5 pounds of $85 \% \mathrm{MnO}_{2}$ per ton of ore. The leached pulp was then filtered and washed with water which had been adjusted to a $\mathrm{pH}$ of 1.5 . The resulting solution was then reduced, using powdered iron, until the terminal emf was $435 \mathrm{mv}$ as measured by the platinum versus the calomel electrode. Calcium oxide 
was added to adjust the $\mathrm{pH}$ to 1.35 and the pregnant solution was filtered to remove excess iron and gypsum. The weight ratio of solution to ore was $2.5: 1.0$, resulting in a feed to ion exchange which analyzed as follows:

$\begin{array}{llll}\mathrm{pH} & 1.35 & \mathrm{Fe}^{++} & 0.33 \mathrm{~g} / 1 \\ \mathrm{Emf} & -435 & \mathrm{Fe}^{+++} & 0.42 \mathrm{~g} / 1 \\ \mathrm{U}_{308} & 0.80 \mathrm{~g} / 1 & \mathrm{P}_{2} \mathrm{O}_{5} & 0.044 \mathrm{~g} / 1 \\ \mathrm{~V}_{2} \mathrm{O}_{5} & 0.012 \mathrm{~g} / 1 & \mathrm{SO}_{4}{ }^{+} & 12.95 \mathrm{~g} / 1\end{array}$

A three-column system for the ion exchange testing was employed, i.e., two columns on exhaustion and one column on elution. Each column contained $25 \mathrm{ml}$ of wet settled IRA-400 resin. Third and fourth loadings on each column averaged 65.6 grams of $\mathrm{U}_{3} \mathrm{O}_{8}$ per liter ( 4.1 pounds/cubic foot) of wet settled resin. The recovery from solution, based on pregnant and barren solution assays, was $99.9 \%$.

Elution was accomplished using a one molar chloride solution. The first 8 bed-volumes of eluate averaged 8 grams of $\mathrm{U}_{3} \mathrm{O}_{8}$ per liter and was precipitated with $\mathrm{NH}_{4} \mathrm{OH}$. The last 8 bed-volumes were recycled. Hydrochloric acid was used to adjust the chloride concentration in the barren eluate to one molar and sulfuric acid was added to adjust the $\mathrm{pH}$ to 1.0. The precipitates, after calcining for two hours at $540^{\circ} \mathrm{C}$, had an average grade of $86.8 \% \mathrm{U}_{3} \mathrm{O}_{8}$.

The indicated reagent consumptions per pound of $\mathrm{U}_{3} \mathrm{O}_{8}$ for elution and precipitation were as follows:

$$
\begin{array}{ll}
\mathrm{HCl} & =0.84 \text { pound }(100 \%) \\
\mathrm{NH}_{3} & =0.75 \text { pound }(100 \%) \\
\mathrm{H}_{2} \mathrm{SO}_{4} & =0.46 \text { pound }(95 \%)
\end{array}
$$

The chemical cost for chloride for column ion exchange could be reduced to some extent by using $\mathrm{NaCl}$ instead of $\mathrm{HCl}$ as a source of chloride.

\section{Settling Tests}

Preliminary settling tests were conducted to determine whether or not the blending of North Jackpile ore with plant feed would introduce settling problems in case a flowsheet, involving either CCD washing or two-stage leaching with RIP, is adopted. Actual determination of thickener size would require testing of blended feeds. Consequently, the study was confined to testing the effectiveness of a few of the available vegetable gums and poly-electrolytes in improving settling rates and clarity of overflow.

Settling tests were made on both leached and unleached pulps at various dilutions. The ore was ground for one minute at $50 \%$ solids (See Table A-2 in the Appendix for screen analyses). The method of Coe and Clevenger was used for measuring the settling rates and calculating the thickener areas. 
Reagents tested as flocculating agents were Dow X-2610, Guartec, Locust Bean Gum, American Cyanamid's S-3000, and Aerofloc No. 548. The effect of these additives on the settling rate and thickener area is shown in the Appendix, Tables A-4 and A-5.

With no flocculating agents, the theoretical area for settling unleached pulp at $3.6: 1$ initial dilution, was 9.3 square feet per ton of ore per day while the leached pulp, at $3.8: 1$ initial dilution, required a theoretical area of only 5.1 square feet per ton of ore per day. Overflow solutions were not clear.

Free settling areas with 0.1 pound of reagent per ton were, in all cases, less than 2.5 square feet per ton per day and the resulting overflow solutions were clear.

The terminal dilution after settling for 20 hours without agitation was about 55 to $59 \%$ solids for unleached pulp, and 43 to $50 \%$ solids for leached pulps.

\section{B. Carbonate Leaching}

1. Test Procedures

In all of the leaching tests, except those done under pressure, the samples were leached in electrically heated, $500 \mathrm{ml}$, three-neck Ace reaction flasks equipped with mechanical agitators and water cooled condensers. The leached pulps were filtered on Buchner funnels and the residues were washed with a volume of hot water equivalent to the weight of the sample leached. The uranium extractions reported in the tables are based upon the residue and feed assays.

A stock solution for leaching was made up, at various times during the testing period, from commercial soda ash and technical grade sodium bicarbonate to correspond to 100 grams of $\mathrm{Na}_{2} \mathrm{CO}_{3}$ and 20 grams of $\mathrm{NaHCO}_{3}$ per liter. However, after the leaching test work had been in progress, it was found that the commercial soda ash had picked up $\mathrm{CO}_{2}$ so that the stock solution varied in concentration from 82 to 92 grams of $\mathrm{Na}_{2} \mathrm{CO}_{3}$ per liter and 30 to 32 grams of $\mathrm{NaHCO}_{3}$ per liter. The stodk leaching solution was used in all of the leaching tests except where prior grinding was involved. These tests were made by adding solid reagents of technical grade.

All of the pressure leaching was done in an electrically heated autoclave fitted with a mechanical agitator. No air other than that originally contained in the autoclave was present during the leaching period. Roasting of the samples was done in an electrically heated muffle furnace. The samples were placed in shallow stainless steel trays and roasted for two hours at $450^{\circ} \mathrm{C}$. The samples were rabbled every 30 minutes. 
Except where indicated, all of the leaching tests were made on 200 gram charges of ore which had been pulverized in a McCool Disc pulverizer. A screen analysis of the pulverized ore is shown in Table III.

\section{Table III}

\section{Screen Analysis of Pulverized Ore}

$\begin{array}{cc}\text { Product } & \frac{\text { Weight }}{16.7} \\ -65+65 & 18.7 \\ -100+150 & 23.2 \\ -150+200 & 19.2 \\ -200+270 & 8.6 \\ -270+325 & 4.0 \\ -325 & 9.6\end{array}$

\section{Effect of Roasting and Oxidant}

A series of tests was made to determine the effect of roasting and oxidant on the extraction of uranium from pulverized ore. Two hundred gram charges of ore were leached at 50\% solids for 18 hours at 95 to $100^{\circ} \mathrm{C}$ with a solution containing 91.7 grams $\mathrm{Na}_{2} \mathrm{CO}_{3}$ and 30.7 grams of $\mathrm{NaHCO}_{3}$ per liter. The oxidants used were air, which was bubbled through the pulp, or potassium permanganate. The results of the tests are summarized in Table IV.

Table IV

Effect of Roast and Oxidant on Uranium Extraction

\begin{tabular}{|c|c|c|c|c|}
\hline $\begin{array}{l}\text { Test } \\
\text { No. }\end{array}$ & $\begin{array}{c}\text { Ore } \\
\text { Condition }\end{array}$ & Oxidant & $\begin{array}{l}\text { Residue } \\
\mathrm{g}_{3} \mathrm{O}_{8}\end{array}$ & $\stackrel{\%}{\text { Extraction }}$ \\
\hline 1 & Raw & None & 0.025 & 87.9 \\
\hline 2 & Raw & Air & 0.016 & 92.3 \\
\hline 3 & Raw & $5 \mathrm{lb} / \mathrm{T} \mathrm{KMnO}$ & 0.014 & 93.2 \\
\hline 4 & Raw & $10 \mathrm{Ib} / \mathrm{T} \mathrm{KMnO}_{4}^{4}$ & 0.010 & 95.2 \\
\hline 5 & Roast & None 4 & 0.011 & 94.7 \\
\hline 6 & Roast & Air & 0.011 & 94.7 \\
\hline 7 & Roast & $5 \mathrm{lb} / \mathrm{T} \mathrm{KMnO}_{4}$ & 0.007 & 96.6 \\
\hline 8 & Roast & $10 \mathrm{Ib} / \mathrm{T} \mathrm{KMnO}_{4}^{4}$ & 0.007 & 96.6 \\
\hline
\end{tabular}

The test data show that without the use of an oxidant, prior roasting increased the uranium extraction by approximately 7\%. The use of air oxidation had no effect on roasted ore but resulted in a $4 \%$ higher extraction from raw ore. The addition of 5 to 10 pounds of $\mathrm{KMnO}_{4}$ per ton of feed increased the uranium extraction from raw ore by 5 to $8 \%$ and by about $2 \%$ from roasted ore.

Consumptions of $\mathrm{Na}_{2} \mathrm{CO}_{3}$, including $\mathrm{NaHCO}_{3}$ calculated as $\mathrm{Na}_{2} \mathrm{CO}_{3}$, were erratic but averaged approximately 13 pounds in those tests when no air oxidation was used, and 18 pounds with air oxidation. 


\section{Effect of Leaching Time}

Tests were made to investigate the effect of leaching time and oxidant on the extraction of uranium from raw and roasted ore. The charges were leached at $50 \%$ solids at 95 to $100^{\circ} \mathrm{C}$ for 6 to 18 hours with a solution containing 82 grams of $\mathrm{Na}_{2} \mathrm{CO}_{3}$ and 32 grams of $\mathrm{NaHCO}_{3}$ per liter. The test results summarized in Table $\mathrm{V}$ indicate that very little would be gained by leaching for more than 6 hours under the conditions studied.

\begin{tabular}{|c|c|c|c|c|c|}
\hline \multirow[b]{2}{*}{$\begin{array}{l}\text { Test } \\
\text { No. }\end{array}$} & \multicolumn{3}{|c|}{ Effect of Leaching Time } & \multirow[b]{2}{*}{$\begin{array}{c}\text { Residue } \\
\text { Assay } \\
\mathrm{oU}_{3} \mathrm{O}_{8}\end{array}$} & \multirow[b]{2}{*}{$\begin{array}{c}\text { Extraction } \\
\mathrm{gu}_{3} \mathrm{O}_{8}\end{array}$} \\
\hline & $\begin{array}{l}\text { Roast at } \\
450^{\circ} \mathrm{C} \\
(2 \mathrm{hrs}) \\
\end{array}$ & Oxidant & $\begin{array}{c}\text { Leach } \\
\text { Time, } \\
\text { Hrs } \\
\end{array}$ & & \\
\hline 1 & None & None & 18 & 0.02 & 90.4 \\
\hline 2 & None & $5 \mathrm{Ib} / \mathrm{T} \mathrm{KMnO}_{4}$ & 18 & 0.013 & 93.7 \\
\hline 3 & Yes & None 4 & 18 & 0.010 & 95.2 \\
\hline 4 & Yes & $5 \mathrm{Ib} / \mathrm{T} \mathrm{KMnO}_{4}$ & 18 & 0.0063 & 97.0 \\
\hline 5 & None & None 4 & 6 & 0.029 & 86.0 \\
\hline 6 & None & $5 \mathrm{lb} / \mathrm{T} \mathrm{KMnO}_{4}$ & 6 & 0.018 & 91.3 \\
\hline 7 & Yes & None & 6 & 0.011 & 94.7 \\
\hline 8 & Yes & $5 \mathrm{Ib} / \mathrm{T} \mathrm{KMnO}_{4}$ & 6 & 0.0083 & 96.0 \\
\hline
\end{tabular}

\section{Effect of Pressure and Temperature}

Four tests using an autoclave as the leaching vessel were made on raw ore pulverized to $83 \%$-65 mesh to determine the effect of higher temperatures and pressures on uranium extraction. Two kilogram charges of ore were leached at $50 \%$ solids with a solution containing 82 grams of $\mathrm{Na}_{2} \mathrm{CO}_{3}$ and 32 grams $\mathrm{NaHCO}_{3}$ per liter. The leaching time was 6 hours. After leaching, the pulps were filtered on Buchner funnels and washed with 2 liters of hot water. The results are shown in Table VI.

The data in Table VI show that $96 \%$ of the uranium was extracted from raw ore by leaching for 6 hours at pressures of 13 to 30 psig and temperatures of 120 to $141^{\circ} \mathrm{C}$, providing an oxidant such as $\mathrm{KMnO}_{4}$ was present。

Table VI

Effect of Pressure and Temperature

\begin{tabular}{|c|c|c|c|c|c|c|}
\hline $\begin{array}{l}\text { Test } \\
\text { No. }\end{array}$ & $\begin{array}{l}\text { Pressure } \\
\text { psig }\end{array}$ & $\begin{array}{c}\text { Temp } \\
{ }^{\circ} \mathrm{C}\end{array}$ & $\begin{array}{l}\mathrm{KMnO} \\
\mathrm{Lb} / \mathrm{T}^{4}\end{array}$ & $\begin{array}{l}\text { Residue } \\
\mathrm{dU}_{3} \mathrm{Og}_{8}\end{array}$ & $\begin{array}{l}\mathrm{WH}_{2} \mathrm{O} \\
\text { Soluble } \mathrm{U}_{3} \mathrm{O}_{8} \\
\text { in Residue }\end{array}$ & $\begin{array}{c}\text { Extraction } \\
\mathrm{qu}_{3} \mathrm{O}_{8}\end{array}$ \\
\hline $\begin{array}{l}1 \\
2 \\
3 \\
4\end{array}$ & $\begin{array}{l}30 \\
30 \\
13 \\
13\end{array}$ & $\begin{array}{l}141 \\
141 \\
120 \\
120\end{array}$ & $\begin{array}{r}0 \\
10 \\
0 \\
10\end{array}$ & $\begin{array}{r}0.204 \\
.009 \\
.100 \\
.009\end{array}$ & $\begin{array}{l}0.075 \\
\text { nil } \\
0.027 \\
\text { nil }\end{array}$ & $\begin{array}{l}36.0 \\
95.8 \\
64.7 \\
95.8\end{array}$ \\
\hline
\end{tabular}


Under comparable conditions, as shown in Table IV, 18 hours were required to achieve the same extraction when raw ore was leached at 95 to $100^{\circ} \mathrm{C}$ at atmospheric pressure.

In the absence of $\mathrm{KMnO}_{4}$, low extractions of uranium were obtained. However, since appreciable amounts of uranium were solubilized when the residue was repulped and washed, it is indicated that reprecipitation of uranium occurred due to reducing conditions from lack of oxygen in the autoclave. It would be desirable to repeat the pressure leaching tests with positive air pressure in the autoclave.

\section{Filtration Tests}

Two tests were made to determine the filtration rates on carbonate leached pulps. The first test was without a flocculent and the second with 0.3 pound Dow $X-2610$ per ton (added as a 1.0 gram per liter solution). The flocculent was added in three stages to the pulp by pouring a stream of one gram per liter solution into a stream of the pulp。

The pulp was prepared by leaching one kilogram of raw ore, pulverized to $87 \%-65$ mesh, with hot carbonate solution $\left(95\right.$ to $100^{\circ} \mathrm{C}$ ) for 18 hours at $50 \%$ solids with five pounds $\mathrm{KMnO}_{4}$ per ton as an oxidant. The leaching solution contained 82 grams of $\mathrm{Na}_{2} \mathrm{CO}_{3}$ per liter and 32 grams of $\mathrm{NaHCO}_{3}$ per liter.

The tests were made using a standard 0.1 square foot Oliver filter leaf with an Eimco filter cloth (Media No. NY-52lF). The pulp temperature was $80^{\circ} \mathrm{C}$ and washing was done using hot water at $80^{\circ} \mathrm{C}$. A specially constructed bath supplied rake agitation similar to that obtained with a drum filter. The results of these tests are shown in Table A-6 in the Appendix。

The data indicate that without the use of a flocculent the maximum filtration rate obtained was 573 pounds per square foot per day at a total cycle time of 3.5 minutes. This rate resulted in a filter cake with a thickness of 1/8". The addition of 0.3 pound Dow X-2610 per ton of ore increased the filtration rate to 677 pounds per square foot per day but yielded a cake having a higher moisture content. 


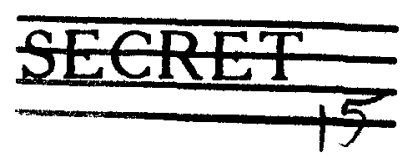

WIN-3

\section{APPENDIX}

Table A-1

\section{Single Stage Acid Leaching}

No Grind (10.4\% +35 mesh, 17.8\% -200 mesh)

Leaching Conditions: Ambient Temperature, 16 hours

\begin{tabular}{|c|c|c|c|c|c|}
\hline $\begin{array}{l}\mathrm{H}_{2} \mathrm{SO}_{4} \\
\mathrm{Lb} / \mathrm{T}\end{array}$ & $\begin{array}{l}\mathrm{MnO}_{2} \\
\mathrm{Lb} / \mathrm{T}\end{array}$ & $\begin{array}{l}\text { Per Cent } \\
\text { Extraction }\end{array}$ & $\begin{array}{c}\text { Residue } \\
\$_{6 U_{3}} \mathrm{O}_{8}\end{array}$ & $\mathrm{pH}$ & emf \\
\hline 60 & 0 & 92.5 & .016 & 0.80 & -.455 \\
\hline 75 & 0 & 92.9 & .015 & 0.68 & -.420 \\
\hline 60 & 5 & 96.7 & .007 & 0.79 & -.545 \\
\hline 75 & 5 & 97.1 & .006 & 0.72 & -.521 \\
\hline 60 & 7.5 & 96.7 & .007 & 0.80 & -.680 \\
\hline
\end{tabular}

Conditions same as above except ore ground 100\% -65 mesh

$\begin{array}{llllll}60 & 0 & 87.8 & .026 & 1.05 & -.370 \\ 75 & 0 & 88.0 & .025 & 0.82 & -.378 \\ 60 & 5 & 92.1 & .017 & 1.10 & -.417 \\ 75 & 5 & 92.3 & .016 & 0.92 & -.412 \\ 60 & 7.5 & 93.2 & .014 & 1.20 & -.417 \\ 75 & 7.5 & 90.4 & .020 & 1.00 & -.403 \\ 75 & 15 & 95.2 & .0099 & 1.2 & -.520 \\ 75 & 30 & 95.6 & .0095 & 1.42 & -.685 \\ 75 & 50 & 96.5 & .0074 & 1.33 & -.700\end{array}$

No Grind

Leaching Conditions: Ambient Temperature, 4 hours

$\begin{array}{llllll}60 & 0 & 87.3 & .027 & 0.60 & -.415 \\ 75 & 0 & 86.9 & .028 & 0.52 & -.415 \\ 60 & 5 & 95.0 & .011 & 0.70 & -.635 \\ 75 & 5 & 95.8 & .009 & 0.52 & -.640 \\ 60 & 7.5 & 95.2 & .010 & 0.72 & -.615 \\ 75 & 7.5 & 93.2 & .014 & 0.50 & -.637\end{array}$

Conditions same as above except ore ground 100\%, -65 mesh

$\begin{array}{llllll}60 & 0 & 81.1 & .040 & 1.00 & -.340 \\ 75 & 0 & 78.2 & .046 & 0.78 & -.360 \\ 60 & 5 & 88.0 & .025 & 1.10 & -.408 \\ 75 & 5 & 87.3 & .027 & 0.82 & -.412 \\ 60 & 7.5 & 89.5 & .022 & 1.2 & -.420 \\ 75 & 7.5 & 86.5 & .028 & 1.0 & -.421\end{array}$

No Grind

Leaching Conditions: $60^{\circ} \mathrm{C}, 4$ hours

$\begin{array}{llllll}60 & 5.0 & 97.2 & .006 & 1.0 & -.490 \\ 75 & 5.0 & 97.2 & .006 & 1.0 & -.570\end{array}$

*Based on residue and feed assays. 


\section{Table A-2}

Screen Analyses of North Jackpile Ore

$\begin{array}{ccccc}\text { Tyler Mesh } & \begin{array}{c}\text { As Prepared } \\ \text { \% Weight }\end{array} & \begin{array}{c}\text { I Min Grind } \\ \text { \% Weight }\end{array} & \begin{array}{c}10 \text { Min Grind } \\ \text { \% Weight }\end{array} \\ -14 & 0.9 & -- & -- \\ -14+20 & 0.8 & -- & -- \\ -28+35 & 5.7 & 0.9 & -- \\ -35+48 & 16.0 & 10.8 & -- \\ -48+65 & 26.0 & 25.3 & 0.6 \\ -65+100 & 16.8 & 5.5 & 14.2 \\ -100+150 & 9.4 & 15.0 & 20.0 \\ -150+200 & 4.6 & 11.3 & 15.3 \\ -200 & 17.8 & 5.6 & 49.9\end{array}$




\section{7}

Table A-3

Two-Stage Cyclic Leaching

\begin{tabular}{|c|c|c|c|c|c|c|c|c|}
\hline Cycle Number & 1 & 2 & 3 & 4 & 5 & 6 & 7 & 8 \\
\hline \multicolumn{9}{|l|}{ First Leach } \\
\hline $\mathrm{pH}$ & - & - & 1.25 & 1.23 & 1.13 & 1.122 & 1.23 & 1.50 \\
\hline $\operatorname{Emf}$ & - & - & 420 & 418 & 416 & 412 & 410 & 389 \\
\hline \multicolumn{9}{|l|}{ Second Leach } \\
\hline 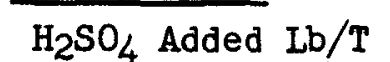 & 52 & 52 & 52 & 52 & 48 & 40 & 35 & 35 \\
\hline $\mathrm{MnO}_{2}{ }^{4}$ Added $\mathrm{Lb} / \mathrm{T}$ & 5 & 5 & 5 & 5 & 5 & 5 & 5 & 5 \\
\hline Emf & - & - & 710 & 685 & 665 & 665 & 600 & 650 \\
\hline $\mathrm{pH}$ & - & - & - & - & - & 0.52 & 1.2 & 1.15 \\
\hline $\mathrm{U}_{3} 08, \mathrm{~g} / 1$ & 0.846 & 0.968 & 1.10 & 1.13 & 1.11 & 1.17 & 1.07 & 1.12 \\
\hline $\mathrm{V}_{2} \mathrm{O}_{5}, \mathrm{~g} / \mathrm{I}$ & 0.004 & 0.004 & 0.004 & 0.016 & 0.016 & 0.020 & 0.023 & 0.004 \\
\hline $\mathrm{Fe}^{++}, \mathrm{g} / 1$ & 0.18 & 0.19 & 0.23 & 0.25 & 0.25 & 0.25 & 0.25 & 0.24 \\
\hline $\mathrm{Fe}^{+++}, \mathrm{g} / 1$ & 0.04 & 0.04 & 0.12 & 0.10 & 0.10 & 0.10 & 0.10 & 0.07 \\
\hline
\end{tabular}

Residue Assay, $\mathrm{qu}_{3} \mathrm{O}_{8}$
$0.0154 \quad 0.0181$
0.0125
$0.0147 \quad 0.011$
0.016
0.012
0.013

苫是

Extraction, \% $\mathrm{U}_{3} \mathrm{O}_{8}$

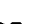

94.0

93.1

94.8

92.5

94.4

93.8 


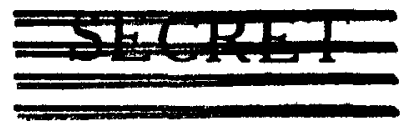

Table A-4

Thickening and Settling of Leached Pulp (pH 1.25)



American Cyanamid

$\begin{array}{ll}n & \text { S-3000 } \\ " 1 & " 1 \\ " & " 1\end{array}$

Amount

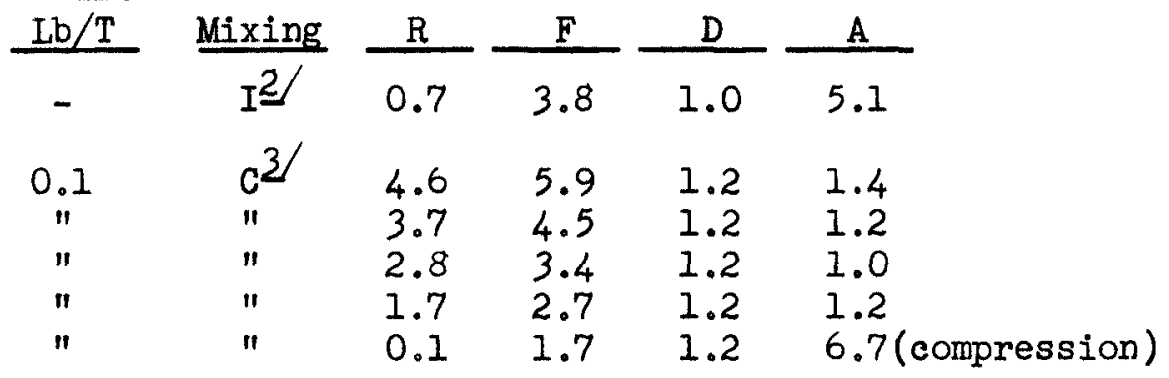

3.4

2.6

1.7

1.3

0.1
5.9

4.5

3.4

2.7

1.7
1.3

1.3

1.3

1.3

1.3

1.8

1.6

1.6

1.4

5.3 (compression)
Guartec
"
"

$\begin{array}{cc}\text { Dow } & X-2610 \\ " ~ & " 10 \\ \text { " } & " 1\end{array}$
0.1
$" 1$
$" 1$

0.1

$"$

$"$

\section{9}

4.5

3.4

2.7

1.7

1.3

1.3

1.3

1.3

1.3

1.2

0.8

5.0

3.8

1.1

1.1

1.1

1.7

2.0

1.6

1.6

1.0

2.9

$\begin{array}{llll}1.4 & 2.2 & 1.1 & 1.8\end{array}$

1 Reagent added in three equal parts.

2) Mixing was accomplished by inverting graduated cylinder several times.

$3 /$ Mixing was accomplished by inverting a rubber stopper on a rod into graduated cylinder and moving it up and down until sands were in suspension.

$F=$ Feed dilution - tons of solution/ton residue.

$D=$ Terminal dilution after 20 hours settlement without mixing.

$R=$ Settling rate in $\mathrm{ft} / \mathrm{hr}$.

$A=$ Thickener area - sq $\mathrm{ft} . / \mathrm{T}$ of residue per day. 


\section{Table A-5}

Thickening and Settling of Unleached Pulp (pH 7.2)

\begin{tabular}{|c|c|c|c|c|c|c|c|}
\hline \multicolumn{3}{|c|}{ Reagent } & $\begin{array}{c}\text { Amount } \\
\mathrm{Ib} / \mathrm{T} \\
\end{array}$ & $\mathbf{R}$ & $F$ & D & A \\
\hline \multicolumn{3}{|c|}{ None } & - & 0.4 & 3.6 & 0.8 & 9.3 \\
\hline $\begin{array}{l}\text { Locust } B \\
"\end{array}$ & Bean Gum & & $\begin{array}{l}0.1 \\
0.2\end{array}$ & $\begin{array}{l}2.9 \\
3.3\end{array}$ & $\begin{array}{l}3.6 \\
3.6\end{array}$ & $\begin{array}{l}0.8 \\
0.8\end{array}$ & $\begin{array}{l}1.3 \\
1.1\end{array}$ \\
\hline American & Cyanamid & $S-3000$ & 0.1 & 1.9 & 3.6 & 0.8 & 2.0 \\
\hline $\begin{array}{cr}\text { Dow } & \text { X-26 } \\
" 1 & " \\
" 1 & " 1 \\
" & \end{array}$ & $\begin{array}{l}10 \\
1 \\
1\end{array}$ & & $\begin{array}{c}0.1 \\
" 1 \\
" 1 \\
" 1\end{array}$ & $\begin{array}{r}117.2 \\
6.6 \\
3.7 \\
1.7 \\
1.6\end{array}$ & $\begin{array}{l}3.6 \\
3.0 \\
2.3 \\
1.5 \\
1.2\end{array}$ & $\begin{array}{l}0.8 \\
" 1 \\
" 1 \\
" ~\end{array}$ & $\begin{array}{l}0.03 \\
0.4 \\
0.5 \\
0.6 \\
0.3\end{array}$ \\
\hline $\begin{array}{c}\text { American } \\
" 1 \\
" \\
"\end{array}$ & $\begin{array}{c}\text { Cyanamid } \\
" \\
" \\
"\end{array}$ & $\begin{array}{c}\# 548 \\
" 1 \\
" \\
"\end{array}$ & $\begin{array}{c}0.1 \\
" 1 \\
" 1\end{array}$ & $\begin{array}{l}2.3 \\
1.5 \\
1.0 \\
0.6\end{array}$ & $\begin{array}{l}3.7 \\
3.1 \\
2.4 \\
1.6\end{array}$ & $\begin{array}{c}0.8 \\
" 1 \\
" 1\end{array}$ & $\begin{array}{l}1.7 \\
2.0 \\
2.3 \\
1.8\end{array}$ \\
\hline $\begin{array}{c}\text { Guartec } \\
\text { " } \\
\text { " }\end{array}$ & & & $\begin{array}{c}0.1 \\
" 1 \\
" 1\end{array}$ & $\begin{array}{l}4.7 \\
3.0 \\
2.3 \\
0.8\end{array}$ & $\begin{array}{l}3.5 \\
2.9 \\
2.3 \\
1.4\end{array}$ & $\begin{array}{l}0.7 \\
" 1 \\
" 1\end{array}$ & $\begin{array}{l}0.8 \\
1.0 \\
0.9 \\
1.2\end{array}$ \\
\hline
\end{tabular}




\section{0}

Table A-6

Filtration Tests on North Jackpile Carbonate Leached Pulps

Pickup Time, Min. Air Dry, Min.

Wash, Min.

Air Dry, Min.

Discharge, Min.

Total Cycle, Min.

Volume Filtrate, $\mathrm{ml}$.

Volume Wash, $\mathrm{ml}$.

Residue Thickness, In.

Residue \% Moisture

Residue Dry Weight, grams

MI Filtrate, $g$ Dry Solid

$\mathrm{Lb} / \mathrm{Ft}^{2} /$ Day

Gal Filtrate/Ft ${ }^{2} /$ Day

Gal Wash/Ft²/Day

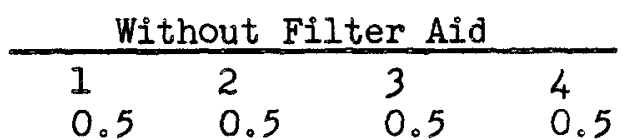

\begin{tabular}{llll}
$0.3 \mathrm{Lb}$ & Dow & $\mathrm{X}-2610 / \mathrm{T}$ & \\
\hline 1 & 2 & 3 & 4 \\
0.5 & 0.5 & 0.5 & 0.5
\end{tabular}

$\begin{array}{llllllll}1 & 2 & 3 & 4 & 1 & 2 & 3 & 4\end{array}$

$\begin{array}{llllllll}1 & 2 & 3 & 4 & 1 & 2 & 3 & 4 \\ 0.5 & 0.5 & 0.5 & 0.5 & 0.5 & 0.5 & 0.5 & 0.5\end{array}$

$\begin{array}{llllllll}0.5 & 0.5 & 0.5 & 0.5 & 0.5 & 0.5 & 0.5 & 0.5\end{array}$

$\begin{array}{llllllll}3.5 & 5.5 & 7.5 & 9.5 & 3.5 & 5.5 & 7.5 & 9.5\end{array}$

$\begin{array}{rrrrrrrr}75 & 110 & 130 & 165 & 75 & 120 & 141 & 144 \\ 40 & 53 & 53 & 62 & 36 & 56 & 64 & 78\end{array}$

$\begin{array}{llllllll}1 / 8 & 3 / 16 & 5 / 16 & 7 / 16 & 1 / 4 & 5 / 16 & 3 / 8 & 3 / 8\end{array}$

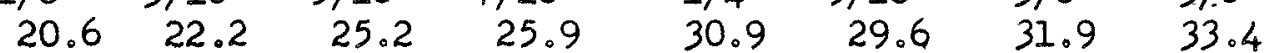

$\begin{array}{llllllll}63 & 90 & 119 & 158 & 74.5 & 108 & 119 & 138\end{array}$

$\begin{array}{llllllll}1.19 & 1.22 & 1.09 & 1.04 & 1.01 & 1.11 & 1.19 & 1.04\end{array}$

$\begin{array}{llllllll}573 & 520 & 505 & 529 & 677 & 624 & 505 & 463\end{array}$

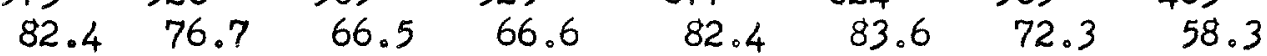

$\begin{array}{llllllll}43.9 & 37.0 & 27.2 & 25.1 & 39.5 & 39.1 & 32.8 & 31.6\end{array}$



$\sum_{j} \sum_{i=1}^{i}$ 

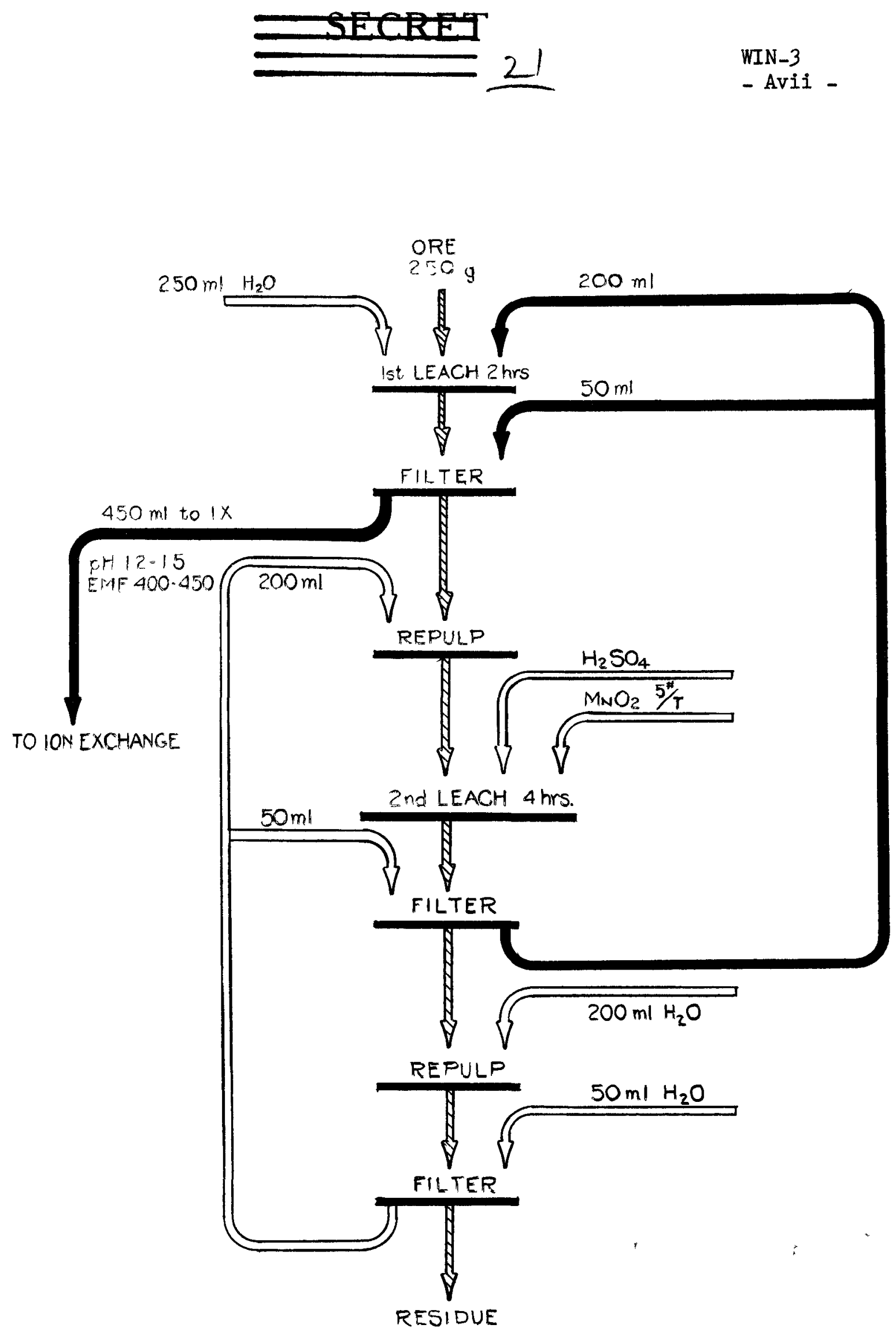

Figure 1. Flowsheet for Two-Stage Leaching Tests

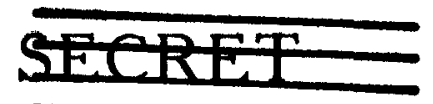

